\title{
Thalassobaculum litoreum gen. nov., sp. nov., a member of the family Rhodospirillaceae isolated from coastal seawater
}

Correspondence

Byung Cheol Cho

bccho@snu.ac.kr

\author{
Gwang I. Zhang, Chung Y. Hwang and Byung C. Cho
}

School of Earth and Environmental Sciences and Research Institute of Oceanography, Seoul National University, San 56-1, Shillim-dong, Kwanak-gu, Seoul 151-742, Republic of Korea
The family Rhodospirillaceae, belonging to subgroup 1 (Woese et al., 1984) of the class Alphaproteobacteria, currently comprises 14 genera (http://www.bacterio. cict.fr). Members of the family Rhodospirillaceae exhibit a variety of modes of growth: the genera Rhodovibrio and Phaeospirillum and some species in three other genera (i.e. Rhodocista centenaria, Rhodospirillum photometricum and Roseospira marina) are capable of both photo- and chemoheterotrophic growth under anoxic conditions in the light and under microoxic to oxic conditions in the dark, respectively (Nissen \& Dundas, 1984; Mack et al., 1993; Garrity et al., 2005). The other species in the genera Rhodospirillum and Roseospira (i.e. Rhodospirillum rubrum, Roseospira mediosalina and Roseospira navarrensis) are capable of photolithoautotrophic growth (with hydrogen or sulfide as an electron donor) as well as the above growth modes (Guyoneaud et al., 2002; Garrity et al., 2005). Other species in the genus Rhodocista (i.e. Rhodocista pekingensis) can grow photo- and chemolitho-heterotrophically (with hydrogen as an electron donor) under anoxic conditions in the light and under oxic conditions in the dark, respectively (Zhang et al., 2003). The genus Rhodospira is capable of photolitho- (with sulfide as an electron donor) and chemoheterotrophic growth under anoxic conditions in the light

The GenBank/EMBL/DDBJ accession number for the $16 \mathrm{~S}$ rRNA gene sequence of strain CL-GR58 ${ }^{\top}$ is EF203900. and under microoxic conditions in the dark, respectively (Pfennig et al., 1997). The genus Telmatospirillum is capable of chemoheterotrophic growth under anoxic to microoxic conditions and both chemolithoheterotrophic and lithoautotrophic growth (with hydrogen as an electron donor), under microoxic conditions (Sizova et al., 2007). Furthermore, chemoheterotrophic genera, Azospirillum (except Azospirillum oryzae which can grow chemolithoheterotrophically utilizing hydrogen as an electron donor; Xie \& Yokota, 2005), Skermanella, Inquilinus, Tistrella, Thalassospira, Defluviicoccus and Magnetospirillum have been reported (Sly \& Stackebrandt, 1999; Coenye et al., 2002; López-López et al., 2002; Shi et al., 2002; Garrity et al., 2005; Maszenan et al., 2005).

Most species in the family Rhodospirillaceae have been isolated from various non-marine habitats such as freshwater, activated sludge biomass, soil and roots of plants and cystic fibrosis patients (Coenye et al., 2002; Garrity et al., 2005). Only limited numbers of members in the family Rhodospirillaceae have been discovered in marine environments (López-López et al., 2002): only five species affiliated with the genera Rhodovibrio (Rhodovibrio salinarum and Rhodovibrio sodomensis; Nissen \& Dundas, 1984; Mack et al., 1993) and Thalassospira (Thalassospira lucentensis, Thalassospira profundimaris and Thalassospira xiamenensis, López-López et al., 2002; Liu et al., 2007) in 
the family Rhodospirillaceae have been isolated from seawater samples.

Here, we describe a chemoheterotrophic bacterium, strain CL-GR58 ${ }^{\mathrm{T}}$, isolated from coastal seawater in Gori, Korea. In August 2005, coastal seawater and sediment samples were brought back to the laboratory and incubated in a $150 \mathrm{~mm}$ diameter glass Petri dish for around 15 months at room temperature. Without disturbing the sediment, a $100 \mu \mathrm{l}$ sample of seawater was removed from the surface and spread on a marine agar 2216 (MA; Difco) plate, which was then incubated at $30{ }^{\circ} \mathrm{C}$ for 1 week. Strain CL-GR58 ${ }^{\mathrm{T}}$ was isolated and subsequently purified on $\mathrm{MA}$ at $30^{\circ} \mathrm{C}$ four times. The strain was maintained both on MA at $30{ }^{\circ} \mathrm{C}$ and in marine broth 2216 (MB; Difco) supplemented with $30 \%(\mathrm{v} / \mathrm{v})$ glycerol at $-80{ }^{\circ} \mathrm{C}$.

The 16S rRNA gene was amplified from a single colony by using PCR with Taq DNA polymerase (Bioneer) and primers 27F and 1492R (Lane, 1991). The PCR product was purified by using the AccuPrep PCR purification kit (Bioneer) and direct sequence determination of the purified 16S rRNA gene was performed with an Applied Biosystems automated sequencer (ABI3730XL) at Macrogen, Seoul, Korea. The almost-complete 16S rRNA gene sequence of strain CL-GR58 ${ }^{\mathrm{T}}$ (1336 nucleotides) was obtained and compared with available $16 \mathrm{~S}$ rRNA gene sequences in GenBank using BLASTN searches (Altschul et al., 1990). The sequence of strain CL-GR58 ${ }^{\mathrm{T}}$ was manually aligned with all available $16 \mathrm{~S}$ rRNA gene sequences of recognized species in the family Rhodospirillaceae obtained from GenBank and Ribosomal Database Project (Cole et al., 2003) databases using known $16 \mathrm{~S}$ rRNA secondary structure information. Phylogenetic trees were constructed by neighbour-joining (Saitou \& Nei, 1987), maximum-parsimony (Fitch, 1971) and maximumlikelihood (Felsenstein, 1981) methods. An evolutionary distance matrix for the neighbour-joining method was generated according to the model of Jukes \& Cantor (1969). The robustness of the tree topologies was assessed by bootstrap analyses based on 1000 replications for the neighbour-joining and maximum-parsimony methods and 100 replications for the maximum-likelihood method. Alignment analysis was carried out using the jPHYDIT program (Jeon et al., 2005) and phylogenetic analyses were carried out using MEGA 3 (Kumar et al., 2004) and PAUP 4.0 (Swofford, 1998). Likelihood parameters were estimated by using the hierarchical ratio test in MODELTEST, version 3.04 (Posada \& Crandall, 1998).

The fatty acid methyl esters in whole cells of strain CLGR58 ${ }^{\mathrm{T}}$ grown on MA at $30{ }^{\circ} \mathrm{C}$ for 5 days were analysed with gas chromatography according to the instructions of the Microbial Identification System (MIDI) at the Korean Culture Center of Microorganisms (KCCM) in Seoul, Korea. The DNA G+C content was analysed by HPLC (HP 100; Hewlett Packard) analysis of deoxyribonucleosides as described by Mesbah et al. (1989), after DNA extraction according to the method of Marmur (1961).
Lambda DNA was used as a standard. The quinone system was determined according to Minnikin et al. (1984) and analysed by HPLC as described by Collins (1985).

Morphological and physiological characteristics were determined. Gram-staining was performed as described by Smibert \& Krieg (1994). Cell motility was observed by the hanging drop method (Suzuki et al., 2001). Cell morphology and presence of flagella was observed using transmission electron microscopy (EX2; JEOL). Anaerobic growth was checked on MA using the GasPak anaerobic system (BBL). Poly- $\beta$-hydroxybutyrate granules were observed by epifluorescence microscopy (BX60; Olympus) after Nile blue A staining (Ostle \& Holt, 1982). Bacteriochlorophyll $a$ production was determined in $90 \%$ acetone extracts using a spectrophotometer (Ultraspec 2000; Pharmacia Biotech) for cells that had been grown either in the light or in the dark for 7 days. The temperature range for growth was examined on the basis of colony formation on MA incubated at temperatures ranging from 5 to $40{ }^{\circ} \mathrm{C}$, using increments of $5{ }^{\circ} \mathrm{C}$. The $\mathrm{pH}$ range ( $\mathrm{pH} 3-10$, using increments of $1 \mathrm{pH}$ unit) for growth was determined by assessing changes in $\mathrm{OD}_{600}$ over the incubation period (up to 7 days) in $\mathrm{MB}$. The final $\mathrm{pH}$ was adjusted using $1 \mathrm{M} \mathrm{NaOH}$ and $1 \mathrm{M} \mathrm{HCl}$ solutions. The tolerance of strain CL-GR58 ${ }^{\mathrm{T}}$ to sea salts was determined both on the basis of colony formation on synthetic Zobell agar (5 g Bacto peptone, $1 \mathrm{~g}$ yeast extract, $0.1 \mathrm{~g}$ ferric citrate, $15 \mathrm{~g}$ Bacto agar, 11 distilled water) and assessing changes in $\mathrm{OD}_{600}$ in Zobell broth with various concentrations $(0-10 \%$ increments of $1 \%$ and $15 \%$, w/v) of sea salts (Sigma). Growth in a medium containing $\mathrm{NaCl}$ as the sole salt was determined both on the basis of colony formation on synthetic Zobell agar and by assessing changes in $\mathrm{OD}_{600}$ in Zobell broth with different concentrations of $\mathrm{NaCl}(0-10 \%$ increments of $1 \%$ and $15 \%$, $\mathrm{w} / \mathrm{v})$. The ability to fix dinitrogen was tested, under anoxic conditions, on $\mathrm{NFb}$ medium $\left(5.0 \mathrm{~g}\right.$ malate, $0.5 \mathrm{~g} \mathrm{~K}_{2} \mathrm{HPO}_{4}$, $0.2 \mathrm{~g} \mathrm{MgSO}_{4} .7 \mathrm{H}_{2} \mathrm{O}, 0.1 \mathrm{~g} \mathrm{NaCl}, 0.02 \mathrm{~g} \mathrm{CaCl}_{2} .2 \mathrm{H}_{2} \mathrm{O}, 2 \mathrm{ml}$ $0.5 \%$ bromothymol blue in $0.2 \mathrm{M} \mathrm{KOH}, 1 \mathrm{ml}$ sterile filtered vitamin solution, $2 \mathrm{ml}$ sterile filtered micronutrient solution, $4 \mathrm{ml} 1.64 \%$ FeEDTA solution, $4.5 \mathrm{~g} \mathrm{KOH}, 11$ distilled water and $15 \mathrm{~g} \mathrm{l}^{-1}$ Bacto agar, at $\mathrm{pH}$ 6.8; Eckert et al., 2001), using Azospirillum doebereinerae KCTC $12904^{\mathrm{T}}$ as the reference strain. Further, the presence of the nifH gene fragment was determined by using PCR amplification with specific primers (PolF/PolR; Poly et al., 2001) for both strain CL-GR58 ${ }^{\mathrm{T}}$ and $A$. doebereinerae KCTC $12904^{\mathrm{T}}$. The oxidase and catalase tests were performed according to the protocols described by Smibert \& Krieg (1994). Gelatinase, amylase and nitrate reductase activities and degradation of Tween 80 were determined according to Hansen \& Sørheim (1991). In addition, other enzyme activities were assayed using the API ZYM kit (bioMérieux) according to the manufacturer's instructions, except that the cell suspension was prepared using artificial seawater $\left(24 \mathrm{~g} \mathrm{NaCl}\right.$, $5.1 \mathrm{~g} \mathrm{MgCl}_{2}$, $4 \mathrm{~g} \mathrm{Na}_{2} \mathrm{SO}_{4}, 1.1 \mathrm{~g} \mathrm{CaCl}_{2}, 0.7 \mathrm{~g} \mathrm{KCl}, 0.2 \mathrm{~g} \mathrm{NaHCO}_{3}, 0.1 \mathrm{~g}$ 
$\mathrm{KBr}, 0.027 \mathrm{~g} \mathrm{H}_{3} \mathrm{BO}_{3}, 0.024 \mathrm{~g} \mathrm{SrCl}_{2}, 0.003 \mathrm{~g} \mathrm{NaF}, 1 \mathrm{l}$ distilled water; Lyman \& Fleming, 1940).

Carbon utilization was tested using the basal broth medium supplemented with yeast extract $(23.6 \mathrm{~g} \mathrm{NaCl}$, $0.64 \mathrm{~g} \mathrm{KCl}, 4.53 \mathrm{~g} \mathrm{MgCl}_{2} .6 \mathrm{H}_{2} \mathrm{O}, 5.94 \mathrm{~g} \mathrm{MgSO}_{4} .7 \mathrm{H}_{2} \mathrm{O}$, $1.3 \mathrm{~g} \mathrm{CaCl}_{2} \cdot 2 \mathrm{H}_{2} \mathrm{O}, 0.2 \mathrm{~g} \mathrm{NaNO}_{3}, 0.2 \mathrm{~g} \mathrm{NH}_{4} \mathrm{Cl}, 0.05 \mathrm{~g}$ yeast extract, 11 distilled water; Bruns et al., 2001) containing $0.4 \%$ carbon source. Strain CL-GR $58^{\mathrm{T}}$ was incubated for 4 weeks and carbon utilization was scored as negative when the growth rate was equal to, or less than, that in the negative control with no carbon source. Growth rate was measured by monitoring changes in $\mathrm{OD}_{600}$. Resistance to antibiotics was determined by the disc diffusion plate method (Bauer et al., 1966).

The $16 \mathrm{~S}$ rRNA gene sequence of strain CL-GR58 ${ }^{\mathrm{T}}$ showed $90.9 \%$ similarity to the type strains of Azospirillum lipoferum, $89.8 \%$ to Azospirillum oryzae, $89.7 \%$ to Azospirillum canadense, $89.5 \%$ to $A$. doebereinerae and $79.3-89.5 \%$ to the other type species of the family
Rhodospirillaceae. Although strain CL-GR58 ${ }^{\mathrm{T}}$ was closely related to species of the genus Azospirillum on the basis of $16 \mathrm{~S}$ rRNA gene sequence similarity, the novel strain was not included in the clade of the genera Azospirillum, Rhodocista or Skermanella (Fig. 1). Further, the lineage of strain CL-GR58 ${ }^{\mathrm{T}}$ was not associated with any other genera of the family Rhodospirillaceae. Therefore, phylogenetically, strain CL-GR58 ${ }^{\mathrm{T}}$ should be recognized as representing a distinct genus in the family Rhodospirillaceae.

The fatty acid profile of strain CL-GR58 ${ }^{\mathrm{T}}$ was composed of $\mathrm{C}_{18: 1} \omega 7 c(48.5 \%), \mathrm{C}_{16: 0}(14.8 \%), \mathrm{C}_{17: 0}(12.2 \%), \mathrm{C}_{19: 0}$ cyclo $\omega 8 c(6.3 \%)$, summed feature 3 (iso- $\mathrm{C}_{15: 0} 2-\mathrm{OH}$ and/ or $\left.\mathrm{C}_{16: 1} \omega 7 c, 6.0 \%\right), 11$-methyl $\mathrm{C}_{18: 1} \omega 7 c(3.0 \%), \mathrm{C}_{18: 0}$ $(2.0 \%), \mathrm{C}_{15: 0}(1.5 \%)$ and an unknown fatty acid (ECL $18.814 ; 1.4 \%$ ) (Table 1 ). Fatty acid $\mathrm{C}_{18: 1} \omega 7 c$ was commonly found as a major component in strain CL$\mathrm{GR}^{\mathrm{T}} 8^{\mathrm{T}}$ and related genera (Table 1); a feature shared by members of the class Alphaproteobacteria (Labrenz et al., 2000). However, a significant amount of $C_{17: 0}(12.2 \%)$

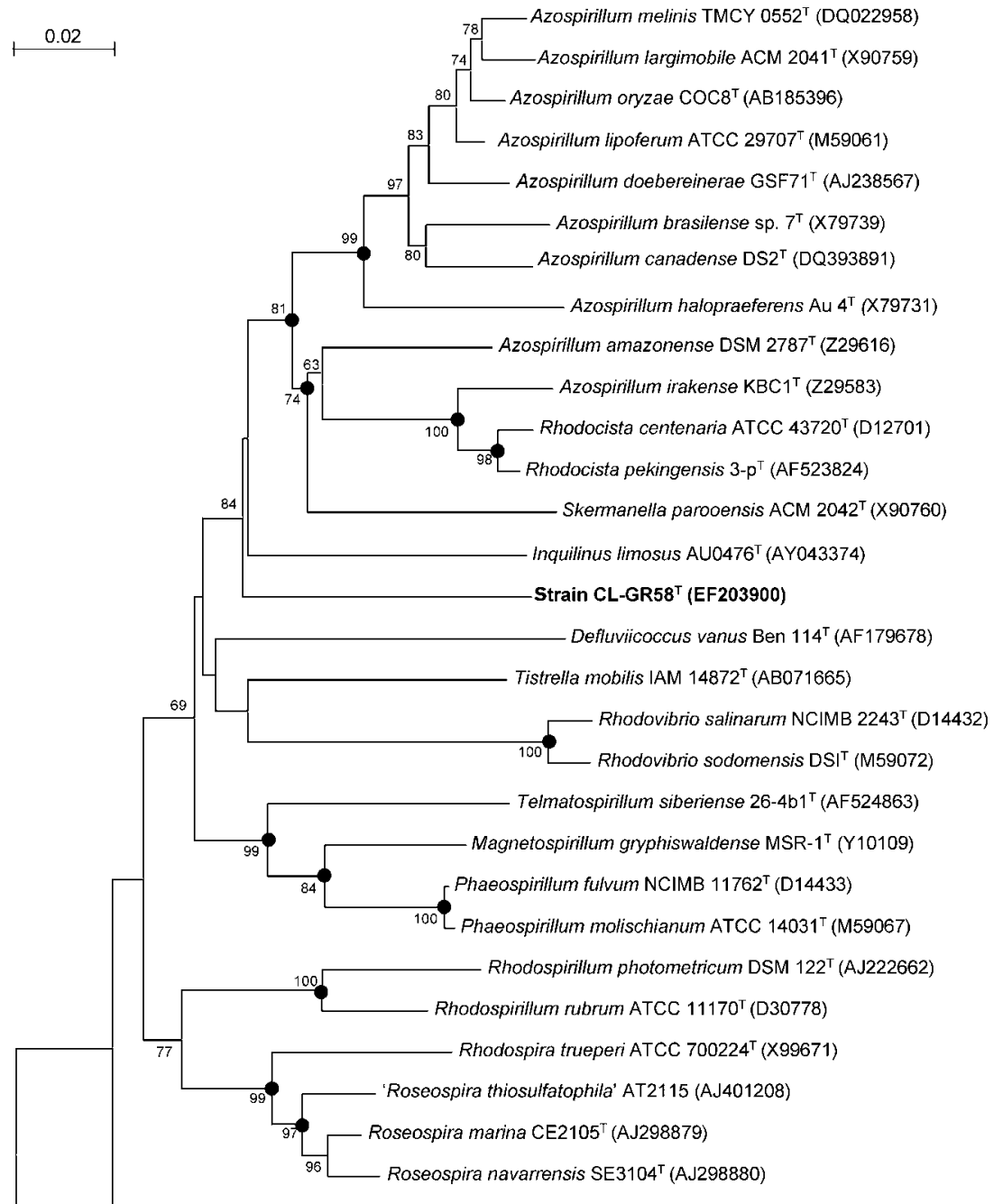

Thalassospira lucentensis $\mathrm{QMT}^{\top}{ }^{\top}$ (AF358664) Escherichia coli ATCC $11775^{\top}$ (X80725)
Fig. 1. Neighbour-joining tree derived from 16S rRNA gene sequences for strain CLGR58 $^{\top}$ and members of the family Rhodospirillaceae with Escherichia coli as an outgroup. Only bootstrap values above $60 \%$ are shown (1000 resamplings) at the branching points. Solid circles indicate that the corresponding nodes were also recovered in maximum-likelihood and maximum-parsimony trees. Bar, 0.02 nucleotide substitutions per site. 
Table 1. Cellular fatty acid content of strain CL-GR58 ${ }^{\top}$ and other phylogenetically related genera of the family Rhodospirillaceae

Taxa: 1. strain CL-GR58 ${ }^{\mathrm{T}}$; 2, Azospirillum (Schenk \& Werner, 1988; López-López et al., 2002; Xie \& Yokota, 2005; Peng et al., 2006; Mehnaz et al., 2007); 3, Rhodovibrio (Imhoff et al., 1998); 4, Tistrella (Shi et al., 2002); 5, Inquilinus (Coenye et al., 2002). ND, Not detected; tr, trace $(<1.0 \%)$; ECL, equivalent chain-length; SF2, summed feature 2, $\mathrm{C}_{12: 0}$ aldehyde, $\mathrm{C}_{16: 1}$ iso $\mathrm{I}$ and/or $\mathrm{C}_{14: 0}$ 3-OH; SF3, summed feature 3, $\mathrm{C}_{16: 1} \omega 7 c$ and/or iso- $\mathrm{C}_{15: 0} 2-\mathrm{OH}$. Data were not available for the genera Rhodocista, Defluviicoccus or Skermanella.

\begin{tabular}{|c|c|c|c|c|c|}
\hline Fatty acid & 1 & 2 & 3 & 4 & 5 \\
\hline $\mathrm{C}_{12: 0}$ & ND & $\mathrm{ND}-5.8$ & $\mathrm{ND}$ & 4.1 & ND \\
\hline $\mathrm{C}_{14: 0}$ & ND & $\mathrm{ND}-2.3$ & 1.0 & $\mathrm{ND}$ & ND \\
\hline $\mathrm{C}_{15: 0}$ & 1.5 & ND-1.5 & ND & $\mathrm{ND}$ & ND \\
\hline $\mathrm{C}_{16: 0}$ & 14.8 & $\mathrm{ND}-12.3$ & 7.4 & 2.6 & $\operatorname{tr}$ \\
\hline $\mathrm{C}_{17: 0}$ & 12.2 & $\operatorname{tr}$ & $\mathrm{ND}$ & $\mathrm{ND}$ & $\operatorname{tr}$ \\
\hline $\mathrm{C}_{18: 0}$ & 2.0 & ND-3.6 & 23.0 & 1.4 & $\operatorname{tr}$ \\
\hline $\mathrm{C}_{16: 0} 2-\mathrm{OH}$ & $\mathrm{ND}$ & $\mathrm{ND}$ & ND & $\mathrm{ND}$ & 5.1 \\
\hline $\mathrm{C}_{16: 0} 3-\mathrm{OH}$ & ND & $\mathrm{ND}-4.8$ & ND & $\operatorname{tr}$ & 3.7 \\
\hline $\mathrm{C}_{17: 0} 2-\mathrm{OH}$ & $\mathrm{ND}$ & $\mathrm{ND}$ & ND & $\mathrm{ND}$ & 5.0 \\
\hline $\mathrm{C}_{17: 0} 3-\mathrm{OH}$ & $\operatorname{tr}$ & $\operatorname{tr}$ & ND & $\mathrm{ND}$ & 4.3 \\
\hline $\mathrm{C}_{18: 0} 3-\mathrm{OH}$ & $\operatorname{tr}$ & $\operatorname{tr}$ & ND & 1.9 & 9.0 \\
\hline $\mathrm{C}_{18: 1} 2-\mathrm{OH}$ & $\mathrm{ND}$ & $\mathrm{ND}-5.5$ & ND & 16.1 & 15.5 \\
\hline $\mathrm{C}_{17: 1} \omega 6 c$ & $\operatorname{tr}$ & ND-7.1 & $\mathrm{ND}$ & $\mathrm{ND}$ & ND \\
\hline $\mathrm{C}_{17: 1} \omega 8 c$ & $\operatorname{tr}$ & ND-3.4 & ND & $\operatorname{tr}$ & ND \\
\hline $\mathrm{C}_{18: 1} \omega 7 c$ & 48.5 & $15.3-75.1$ & $35.2^{\star}$ & 43.4 & 35.6 \\
\hline $\mathrm{C}_{19: 0}$ cyclo $\omega 8 c$ & 6.3 & ND-3.8 & $\mathrm{ND}$ & 5.0 & 7.9 \\
\hline $\mathrm{C}_{20: 1} \omega 9 c$ & $\operatorname{tr}$ & ND & ND & $\mathrm{ND}$ & ND \\
\hline 11-methyl $\mathrm{C}_{18: 1} \omega 7 c$ & 3.0 & ND & ND & 8.5 & ND \\
\hline ECL 18.814 & 1.4 & ND & $\mathrm{ND}$ & $\mathrm{ND}$ & ND \\
\hline SF2 & $\operatorname{tr}$ & $\mathrm{ND}-6.7$ & ND & 8.6 & ND \\
\hline SF3 & 6.0 & $\mathrm{ND}-31.4 \dagger$ & $\operatorname{tr} \ddagger$ & 1.2 & ND \\
\hline
\end{tabular}

${ }^{\star} \mathrm{C}_{18: 1}$.

$\nmid \mathrm{C}_{16: 1} \omega 7 c$ and/or $\mathrm{C}_{16: 1} \omega 6 c$.

$\ddagger \mathrm{C}_{16: 1}$.

was only found in strain CL-GR58 ${ }^{\mathrm{T}}$ and was not found at significant levels in the related genera Azospirillum, Rhodovibrio, Tistrella or Inquilinus (Table 1). Furthermore, the absence of fatty acids $\mathrm{C}_{16: 0} 2-\mathrm{OH}, \mathrm{C}_{16: 0} 3-\mathrm{OH}$, $\mathrm{C}_{17: 0} 2-\mathrm{OH}$ and $\mathrm{C}_{18: 1} 2-\mathrm{OH}$ clearly differentiated strain CL-GR58 ${ }^{\mathrm{T}}$ from the genera Azospirillum, Tistrella and Inquilinus (Table 1). A significant concentration of $\mathrm{C}_{18: 1} 2$ $\mathrm{OH}$ (15.5-16.1\%) observed in the genera Tistrella and Inquilinus was not detected in strain CL-GR58 ${ }^{\mathrm{T}}$ or in the genus Rhodovibrio. Absence of fatty acid $\mathrm{C}_{19: 0}$ cyclo $\omega 8 \mathrm{c}$ differentiated the genus Rhodovibrio from other related genera. Therefore, the fatty acid pattern of strain CLGR $58^{\mathrm{T}}$ differs distinctly from those of related genera in the family Rhodospirillaceae. The major quinone in strain CL$\mathrm{GR}^{2} 8^{\mathrm{T}}$ was ubiquinone $10(\mathrm{Q}-10)$, which is also found in the genera Azospirillum, Tistrella and Skermanella; however in the genera Rhodocista and Rhodovibrio, Q-9, and Q-10 and MK-10 were found, respectively (Table 2 ). The $\mathrm{G}+\mathrm{C}$ content of the DNA was $68.0 \mathrm{~mol} \%$ (Table 2).

Cells of strain CL-GR58 ${ }^{\mathrm{T}}$ were Gram-negative, slightly curved and straight rod-shaped and approximately 0.3$0.5 \mu \mathrm{m}$ wide and $1.3-1.5 \mu \mathrm{m}$ long. Cells were motile by means of a polar flagellum. Colonies were circular, convex and cream-yellow on MA plates. After 10 days on MA at $30{ }^{\circ} \mathrm{C}$, colonies were approximately $1 \mathrm{~mm}$ in diameter. Strain CL-GR58 ${ }^{\mathrm{T}}$ was heterotrophic and facultatively anaerobic. Cells contained poly- $\beta$-hydroxybutyrate granules. Bacteriochlorophyll $a$ was not detected. The optimum growth temperature was $30-35{ }^{\circ} \mathrm{C}$; the optimum pH was 8 . Growth occurred at sea salts concentrations of $1-10 \%$ (w/v; optimum 2-4\%), but no growth occurred in media containing only $\mathrm{NaCl}$ as a salt. Strain CL-GR58 ${ }^{\mathrm{T}}$ was unable to fix dinitrogen and did not possess a nifH gene, whereas $A$. doebereinerae was able to grow on the $\mathrm{NFb}$ medium by fixing nitrogen and had a nifH gene (data not shown). Oxidase, catalase, gelatinase, nitrate reductase and amylase activities were positive. Tween 80 was not hydrolysed. According to API ZYM tests, alkaline phosphatase, esterase (C4), leucine arylamidase, valine arylamidase, acid phosphatase, naphthol-AS-BI-phosphohydrolase, $\alpha$ - and $\beta$-glucosidases and $N$-acetyl- $\beta$-glucosaminidase activities were positive and were weakly positive for esterase lipase (C8), lipase (C14), $\alpha$ - and $\beta$-galactosidases, $\alpha$-mannosidase and $\alpha$-fucosidase. No activities were found for cystine arylamidase, trypsin, $\alpha$-chymotrypsin and $\beta$-glucuronidase. Growth occurred on D-ribose, sucrose, Larabinose and yeast extract. No growth occurred on acetate, $\alpha$-ketobutyric acid, citrate, fructose, galactose, glucose, mannitol, raffinose, salicin, trehalose, ethanol, inositol, inulin, lactose, L-lysine, L-rhamnose, $\mathrm{N}$-acetylglucosamine, oxalic acid, pyruvic acid, succinate or L-proline. Strain CL-GR58 ${ }^{\mathrm{T}}$ was susceptible to streptomycin, gentamicin, vancomycin, kanamycin, penicillin, erythromycin, tetracycline, chloramphenicol, ciprofloxacin and ampicillin, but resistant to mitomycin $\mathrm{C}$, nalidixic acid and polymyxin $\mathrm{B}$.

Strain CL-GR58 ${ }^{\mathrm{T}}$ could be differentiated phenotypically from the genus Azospirillum by its inability to perform nitrogen fixation and from the genera Rhodocista and Rhodovibrio by the absence of bacteriochlorophyll $a$ (Table 2). Strain CL-GR58 ${ }^{\mathrm{T}}$ could be differentiated from members of the genus Defluviicoccus by some phenotypic features (presence of flagella, positive activity for oxidase) and from the genus Skermanella by the positive activity for gelatinase. The growth temperature range distinguished strain CL-GR5 $8^{\mathrm{T}}\left(10-35^{\circ} \mathrm{C}\right)$ from members of the genus Inquilinus $\left(25-42{ }^{\circ} \mathrm{C}\right)$. In addition, the salt tolerance range distinguished strain CL-GR58 ${ }^{\mathrm{T}}(1-10 \%)$ from the genera Azospirillum $(<5 \%)$, Tistrella $(<1 \%)$, Skermanella $(<5 \%)$ and Inquilinus $(<6 \%)$ (Table 2$)$.

In conclusion, phylogenetic analyses based on 16S rRNA gene sequences, chemotaxonomic data (fatty acid profiles, 
Table 2. Selected characteristics that differentiate strain CL-GR58 ${ }^{\top}$ from other phylogenetically related genera in the family Rhodospirillaceae

Taxa: 1, strain CL-GR58 ${ }^{\mathrm{T}}$; 2, Azospirillum (Tarrand et al., 1978; Reinhold et al., 1987; Khammas et al., 1989; Sly \& Stackebrandt, 1999; Eckert et al., 2001; Xie \& Yokota, 2005; Peng et al., 2006; Mehnaz et al., 2007); 3, Rhodocista (Favinger et al., 1989; Kawasaki et al., 1992; Imhoff et al., 1998; Zhang et al., 2003); 4, Rhodovibrio (Nissen \& Dundas, 1984; Mack et al., 1993; Imhoff et al., 1998; Garrity et al., 2005); 5, Defluviicoccus (Maszenan et al., 2005); 6, Tistrella (Shi et al., 2002); 7, Skermanella (Sly \& Stackebrandt, 1999); 8, Inquilinus (Coenye et al., 2002). +, Positive; w, weakly positive; -, negative; v, variable; MP, monopolar; BP, bipolar; NA, not available. All strains are Gram-negative and catalase-positive (data for catalase were not available for the genera Rhodocista and Rhodovibrio).

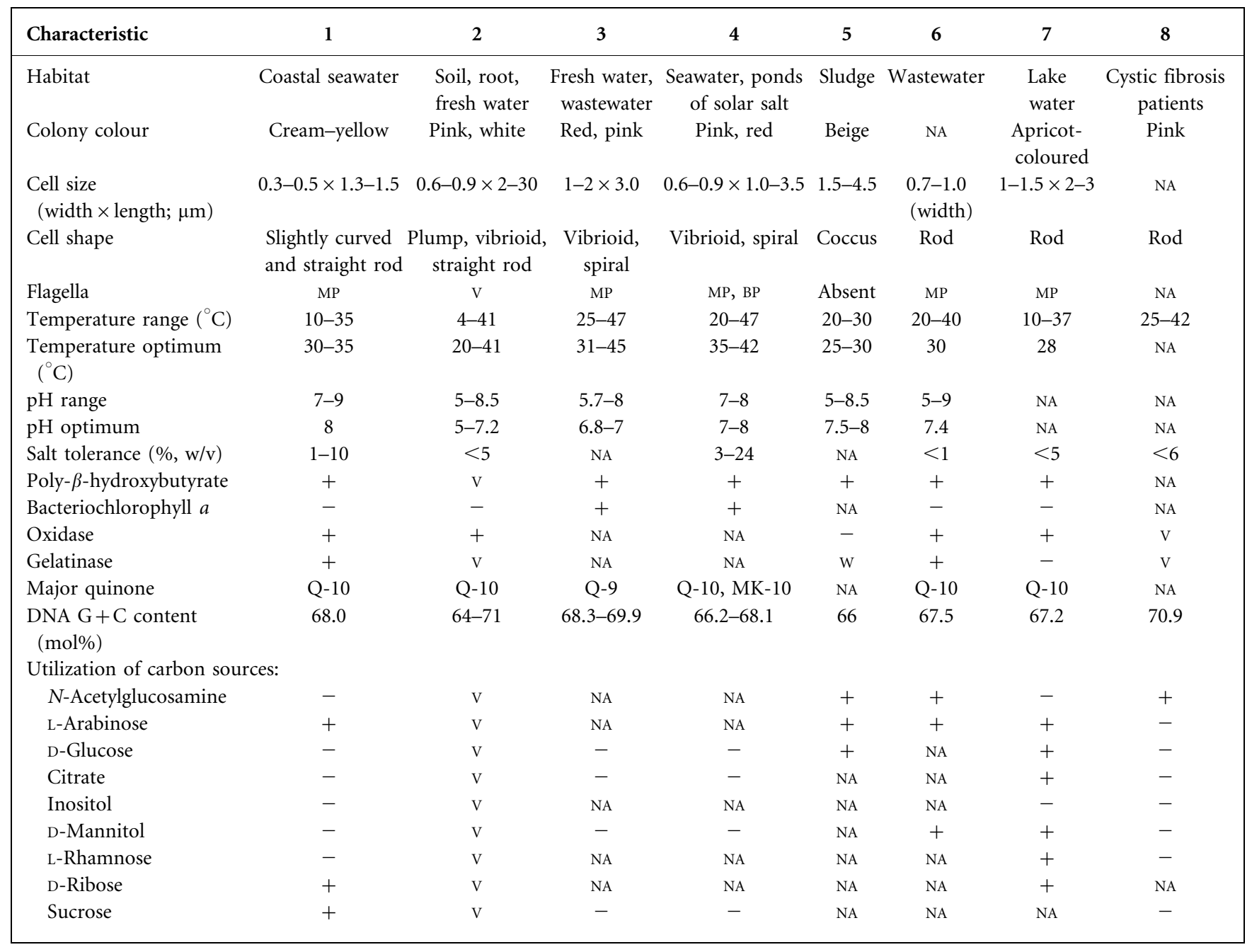

quinones) and phenotypic traits indicated that strain CLGR58 ${ }^{\mathrm{T}}$ should be classified as a novel genus and species, for which the name Thalassobaculum litoreum gen. nov., sp. nov. is proposed.

\section{Description of Thalassobaculum gen. nov.}

Thalassobaculum (Tha.las'so.ba.cu.lum. Gr. n. Thalassa the sea; L. neut. n. baculum stick; N.L. neut. n. Thalassobaculum rod-shaped bacterium from the sea).

Cells are Gram-negative, slightly curved and straight rodshaped and are motile by means of a polar flagellum. Growth is heterotrophic and facultatively anaerobic. Oxidase- and catalase-positive. Bacteriochlorophyll $a$ is not detected. Unable to fix dinitrogen under anoxic conditions. Dominant cellular fatty acids are $\mathrm{C}_{18: 1} \omega 7 c, \mathrm{C}_{16: 0}, \mathrm{C}_{17: 0}$, $\mathrm{C}_{19: 0}$ cyclo $\omega 8 c$ and summed feature $3\left(\mathrm{C}_{16: 1} \omega 7 c\right.$ and/or iso- $\left.\mathrm{C}_{15: 0} 2-\mathrm{OH}\right)$. The isoprenoid quinone is $\mathrm{Q}-10$. The $\mathrm{G}+\mathrm{C}$ content of the DNA is $68.0 \mathrm{~mol} \%$. Phylogenetically, the genus is a member of the family Rhodospirillaceae. The type species is Thalassobaculum litoreum.

Description of Thalassobaculum litoreum sp. nov.

Thalassobaculum litoreum (li.to.re'um. L. neut. adj. litoreum of the shore). 
Displays the following properties in addition to those given in the genus description. Colonies are circular, convex and cream-yellow on marine agar plates. After 10 days on MA at $30{ }^{\circ} \mathrm{C}$, colonies are approximately $1 \mathrm{~mm}$ in diameter. Cells are approximately $0.3-0.5 \mu \mathrm{m}$ wide and $1.3-1.5 \mu \mathrm{m}$ long. Grows at between 10 and $35^{\circ} \mathrm{C}$ (optimum of 30 $35{ }^{\circ} \mathrm{C}$ ) and $\mathrm{pH}$ 7-9 (optimum of $\mathrm{pH}$ 8). Growth occurs at sea salts concentrations of $1-10 \%(\mathrm{w} / \mathrm{v})$ (optimum $2-4 \%$ ), but no growth occurs in media containing only $\mathrm{NaCl}$ as a salt. Cells contain poly- $\beta$-hydroxybutyrate granules. Gelatinase and amylase are produced. Tween 80 is not hydrolysed. Nitrate is reduced to nitrite. Positive for the following enzyme activities as tested with the API ZYM system: alkaline phosphatase, esterase (C4), leucine arylamidase, valine arylamidase, acid phosphatase, naphtholAS-BI-phosphohydrolase, $\alpha$ - and $\beta$-glucosidases and $N$ acetyl- $\beta$-glucosaminidase; weakly positive for esterase lipase (C8), lipase (C14), $\alpha$ - and $\beta$-galactosidases, $\alpha$ mannosidase and $\alpha$-fucosidase. No activities for cystine arylamidase, trypsin, $\alpha$-chymotrypsin and $\beta$-glucuronidase. D-ribose, sucrose, L-arabinose and yeast extract are utilized as carbon sources. Negative for utilization of the following: acetate, $\alpha$-ketobutyric acid, citrate, fructose, galactose, glucose, mannitol, raffinose, salicin, trehalose, ethanol, inositol, inulin, lactose, L-lysine, L-rhamnose, $\mathrm{N}$-acetylglucosamine, oxalic acid, pyruvic acid, succinate and L-proline. Cells are sensitive to ( $\mu \mathrm{g}$ per disc): streptomycin (10), gentamicin (10), vancomycin (30), kanamycin (30), penicillin (10), erythromycin (15), tetracycline (30), chloramphenicol (30), ciprofloxacin (5) and ampicillin (10).

The type strain, CL-GR58 ${ }^{\mathrm{T}} \quad\left(=\mathrm{KCCM} \quad 42674^{\mathrm{T}}=\mathrm{DSM}\right.$ $18839^{\mathrm{T}}$ ), was isolated from coastal seawater, Korea.

\section{Acknowledgements}

We would like to thank Ms Yeon-A Jin for helping with strain isolation. We also acknowledge the expert technical support of Ms InSung Lee (electron microscopy) of the National Center for Interuniversity Research Facilities at Seoul National University. This work was supported in part by the BK21 project of the Korean Government and the Ministry of Maritime Affairs and Fisheries (the Korea EAST-1 program).

\section{References}

Altschul, S. F., Gish, W., Miller, W., Myers, E. W. \& Lipman, D. J. (1990). Basic local alignment search tool. J Mol Biol 215, 403-410.

Bauer, A. W., Kirby, W. M. M., Sherris, J. C. \& Turck, M. (1966). Antibiotic susceptibility testing by a standardized single disk method. Am J Clin Pathol 45, 493-496.

Bruns, A., Rohde, M. \& Berthe-Corti, L. (2001). Muricauda ruestringensis gen. nov., sp. nov., a facultatively anaerobic, appendaged bacterium from German North Sea intertidal sediment. Int $J$ Syst Evol Microbiol 51, 1997-2006.

Coenye, T., Goris, J., Spilker, T., Vandamme, P. \& LiPuma, J. J. (2002). Characterization of unusual bacteria isolated from respiratory secretions of cystic fibrosis patients and description of Inquilinus limosus gen. nov., sp. nov. J Clin Microbiol 40, 2062-2069.
Cole, J. R., Chai, B., Marsh, T. L., Farris, R. J., Wang, Q., Kulam, S. A., Chandra, S., McGarrell, D. M., Schmidt, T. M. \& other authors (2003). The ribosomal database project (RDP-II): previewing a new autoaligner that allows regular updates and the new prokaryotic taxonomy. Nucleic Acids Res 31, 442-443.

Collins, M. D. (1985). Analysis of isoprenoid quinones. Methods Microbiol 18, 329-366.

Eckert, B., Weber, O. B., Kirchhof, G., Halbritter, A., Stoffels, M. \& Hartmann, A. (2001). Azospirillum doebereinerae sp. nov., a nitrogenfixing bacterium associated with the C4-grass Miscanthus. Int J Syst Evol Microbiol 51, 17-26.

Favinger, J., Stadtwald, R. \& Howard, G. (1989). Rhodospirillum centenum, sp. nov., a thermotolerant cyst-forming anoxygenic photosynthetic bacterium. Antonie van Leeuwenhoek 55, 291-296.

Felsenstein, J. (1981). Evolutionary trees from DNA sequences: a maximum likelihood approach. J Mol Evol 17, 368-376.

Fitch, W. M. (1971). Toward defining the course of evolution: minimum change for a specific tree topology. Syst Zool 20, 406-416.

Garrity, G. M., Bell, J. A. \& Lilburn, T. (2005). Family I. Rhodospirillaceae Pfennig and Trüper 1971, 17 ${ }^{\mathrm{AL}}$. In Bergey's Manual of Systematic Bacteriology, 2nd edn, vol. 2, The Proteobacteria, part C, The Alpha-, Beta-, Delta-, and Epsilonprotebacteria, pp. 1-40. Edited by D. J. Brenner, N. R. Krieg, J. T. Staley \& G. M. Garrity. New York: Springer.

Guyoneaud, R., Mouné, S., Eatock, C., Bothorel, V., Hirschler-Réa, A., Willison, J., Duran, R., Liesack, W., Herbert, R. \& other authors (2002). Characterization of three spiral-shaped purple nonsulfur bacteria isolated from coastal lagoon sediments, saline sulfur springs, and microbial mats: emended description of the genus Roseospira and description of Roseospira marina sp. nov., Roseospira navarrensis sp. nov., and Roseospira thiosulfatophila sp. nov. Arch Microbiol 178, 315-324.

Hansen, G. H. \& Sørheim, R. (1991). Improved method for phenotypical characterization of marine bacteria. $J$ Microbiol Methods 13, 231-241.

Imhoff, J. F., Petri, R. \& Suling, J. (1998). Reclassification of species of the spiral-shaped phototrophic purple non-sulfur bacteria of the $\alpha$ Proteobacteria: description of the new genera Phaeospirillum gen. nov., Rhodovibrio gen. nov., Rhodothalassium gen. nov. and Roseospira gen. nov. as well as transfer of Rhodospirillum fulvum to Phaeospirillum fulvum comb. nov., of Rhodospirillum molischianum to Phaeospirillum molischianum comb. nov., of Rhodospirilium salinarum to Rhodovibrio salinarum comb. nov., of Rhodospirillum sodomense to Rhodovibrio sodomensis comb. nov., of Rhodospirillum salexigens to Rhodothalassium salexigens comb. nov. and of Rhodospirillum mediosalinum to Roseospira mediosalina comb. nov. Int J Syst Bacteriol 48, 793-798.

Jeon, Y.-S., Chung, H., Park, S., Hur, I., Lee, J.-H. \& Chun, J. (2005). jPHYDIT: a JAVA-based integrated environment for molecular phylogeny of ribosomal RNA sequences. Bioinformatics 21, 3171-3173.

Jukes, T. H. \& Cantor, C. R. (1969). Evolution of protein molecules. In Mammalian Protein Metabolism, vol. 3, pp. 21-132. Edited by H. N. Munro. New York: Academic Press.

Kawasaki, H., Hoshino, Y., Kuraiski, Y. \& Yamasato, K. (1992). Rhodocista centenaria gen. nov., sp. nov., a cyst-forming anoxygenic photosynthetic bacterium and its phylogenetic position in the Proteobacteria alpha group. J Gen Appl Microbiol 38, 541-551.

Khammas, K. M., Ageron, E., Grimont, P. A. D. \& Kaiser, P. (1989). Azospirillum irakense sp. nov., a nitrogen-fixing bacterium associated with rice roots and rhizosphere soil. Res Microbiol 140, 679-693.

Kumar, S., Tamura, K. \& Nei, M. (2004). MEGA 3: integrated software for molecular evolutionary genetics analysis and sequence alignment. Brief Bioinform 5, 150-163. 
Labrenz, M., Tindall, B. J., Lawson, P. A., Collins, M. D., Schumann, P. \& Hirsch, P. (2000). Staleya guttiformis gen. nov., sp. nov. and Sulfitobacter brevis sp. nov., $\alpha$-3-Proteobacteria from hypersaline, heliothermal and meromictic antarctic Ekho Lake. Int J Syst Evol Microbiol 50, 303-313.

Lane, D. J. (1991). 16S/23S rRNA sequencing. In Nucleic Acid Techniques in Bacterial Systematics, pp. 115-175. Edited by E. Stackebrandt \& M. Goodfellow. Chichester: Wiley.

Liu, C., Wu, Y., Li, L., Ma, Y. \& Shao, Z. (2007). Thalassospira xiamenensis sp. nov. and Thalassospira profundimaris sp. nov. Int $J$ Syst Evol Microbiol 57, 316-320.

López-López, A., Pujalte, M. J., Benlloch, S., Mata-Roig, M., Rosselló-Mora, R., Garay, E. \& Rodríguez-Valera, F. (2002). Thalassospira lucentensis gen. nov., sp. nov., a new marine member of the $\alpha$-Proteobacteria. Int J Syst Evol Microbiol 52, 1277-1283.

Lyman, J. \& Fleming, R. H. (1940). Composition of sea water. J Mar Res 3, 134-146.

Mack, E. E., Mandelco, L., Woese, C. R. \& Madigan, M. T. (1993). Rhodospirillum sodomense, sp. nov., a Dead Sea Rhodospirillum species. Arch Microbiol 160, 363-371.

Marmur, J. (1961). A procedure for the isolation of deoxyribonucleic acid from microorganisms. J Mol Biol 3, 208-218.

Maszenan, A. M., Seviour, R. J., Patel, B. K. C., Janssen, P. H. \& Wanner, J. (2005). Defluvicoccus vanus gen. nov., sp. nov., a novel Gram-negative coccus/coccobacillus in the 'Alphaproteobacteria' from activated sludge. Int J Syst Evol Microbiol 55, 2105-2111.

Mehnaz, S., Weselowski, B. \& Lazarovits, G. (2007). Azospirillum canadense sp. nov., a nitrogen-fixing bacterium isolated from corn rhizosphere. Int J Syst Evol Microbiol 57, 620-624.

Mesbah, M., Premachandran, U. \& Whitman, W. B. (1989). Precise measurement of the $\mathrm{G}+\mathrm{C}$ content of deoxyribonucleic acid by highperformance liquid chromatography. Int J Syst Bacteriol 39, 159-167.

Minnikin, D. E., O’Donnell, A. G., Goodfellow, M., Alderson, G., Athalye, M., Schaal, K. \& Parlett, J. H. (1984). An integrated procedure for the extraction of bacterial isoprenoid quinones and polar lipids. J Microbiol Methods 2, 233-241.

Nissen, H. \& Dundas, I. D. (1984). Rhodospirillum salinarum sp. nov., a halophilic photosynthetic bacterium isolated from a Portuguese saltern. Arch Microbiol 138, 251-256.

Ostle, A. G. \& Holt, J. G. (1982). Nile blue A as fluorescent stain for poly- $\beta$-hydroxybutyrate. Appl Environ Microbiol 44, 238-241.

Peng, G., Wang, H., Zhang, G., Hou, W., Liu, Y., Wang, E. T. \& Tan, Z. (2006). Azospirillum melinis sp. nov., a group of diazotrophs isolated from tropical molasses grass. Int J Syst Evol Microbiol 56, 1263-1271.

Pfennig, N., Lünsdorf, H., Süling, J. \& Imhoff, J. F. (1997). Rhodospira trueperi gen. nov., a new phototrophic Proteobacterium of the alpha group. Arch Microbiol 168, 39-45.

Poly, F., Monrozier, L. J. \& Bally, R. (2001). Improvement in the RFLP procedure for studying the diversity of nifH genes in the communities of nitrogen fixers in soil. Res Microbiol 152, 95-103.

Posada, D. \& Crandall, K. A. (1998). MODELTEST: testing the model of DNA substitution. Bioinformatics 14, 817-818.
Reinhold, B., Hurek, T., Fendrik, I., Pot, B., Gillis, M., Kersters, K., Thielemans, S. \& De Ley, J. (1987). Azospirillum halopraeferens sp. nov., a nitrogen-fixing organism associated with roots of Kallar Grass (Leptochloa fusca (L.) Kunth). Int J Syst Bacteriol 37, 43-51.

Saitou, N. \& Nei, M. (1987). The neighbor-joining method: a new method for reconstructing phylogenetic trees. Mol Biol Evol 4, 406-425.

Schenk, S. U. \& Werner, D. (1988). Fatty acid analysis of four Azospirillum species reveals three groups. Arch Microbiol 149, 580-582.

Shi, B. H., Arunpairojana, V., Palakawong, S. \& Yokota, A. (2002). Tistrella mobilis gen. nov., sp. nov., a novel polyhydroxyalkanoateproducing bacterium belonging to $\alpha$-Proteobacteria. J Gen Appl Microbiol 48, 335-343.

Sizova, M. V., Panikov, N. S., Spiridonova, E. M., Slobodova, N. V. \& Tourova, T. P. (2007). Novel facultative anaerobic acidotolerant Telmatospirillum siberiense gen. nov., sp. nov., isolated from mesotrophic fen. Syst Appl Microbiol 30, 213-220.

Sly, L. I. \& Stackebrandt, E. (1999). Description of Skermanella parooensis gen. nov., sp. nov. to accommodate Conglomeromonas largomobilis subsp. parooensis following the transfer of Conglomeromonas largomobilis subsp. largomobilis to the genus Azospirillum. Int J Syst Bacteriol 49, 541-544.

Smibert, R. M. \& Krieg, N. R. (1994). Phenotypic characterization. In Methods for General and Molecular Bacteriology, pp. 607-654. Edited by P. Gerhardt, R. G. E. Murray, W. A. Wood \& N. R. Krieg. Washington, DC: American Society for Microbiology.

Suzuki, M., Nakagawa, Y., Harayama, S. \& Yamamoto, S. (2001). Phylogenetic analysis and taxonomic study of marine Cytophaga-like bacteria: proposal for Tenacibaculum gen. nov. with Tenacibaculum maritimum comb. nov. and Tenacibaculum ovolyticum comb. nov., and description of Tenacibaculum mesophilum sp. nov. and Tenacibaculum amylolyticum sp. nov. Int J Syst Evol Microbiol 51, 1639-1652.

Swofford, D. L. (1998). PAUP-phylogenetic analysis using parsimony, version 4. Sunderland, MA: Sinauer Associates.

Tarrand, J. J., Krieg, N. R. \& Döbereiner, J. (1978). A taxonomic study of the Spirillum lipoferum group, with description of a new genus, Azospirillum gen. nov., and two species, Azospirillum lipoferum (Beijerinck) comb. nov., and Azospirillum brasilense sp. nov. Can J Microbiol 24, 967-980.

Woese, C. R., Stackebrandt, E., Weisburg, W. G., Paster, B. J., Madigan, M. T., Fowler, V. J., Hahn, C. M., Blanz, P., Gupta, R. \& other authors (1984). The phylogeny of purple bacteria: the alpha subdivision. Syst Appl Microbiol 5, 315-326.

Xie, C.-H. \& Yokota, A. (2005). Azospirillum oryzae sp. nov., a nitrogen-fixing bacterium isolated from the roots of the rice plant Oryza sativa. Int J Syst Evol Microbiol 55, 1435-1438.

Zhang, D., Yang, H., Zhang, W., Huang, Z. \& Liu, S.-J. (2003). Rhodocista pekingensis sp. nov., a cyst-forming phototrophic bacterium from a municipal wastewater treatment plant. Int J Syst Evol Microbiol 53, 1111-1114. 